\title{
Impacts of light rail in a mid-sized city: Evidence from Olsztyn, Poland
}

\author{
Jędrzej Gadziński \\ Adam Mickiewicz University
}

\author{
Adam Radzimski (corresponding author) \\ Adam Mickiewicz University \\ adam.radzimski@amu.edu.pl
}

\begin{abstract}
Investments in light rail transit (LRT) have become increasingly popular solutions to promote sustainable urban transportation. However, their impacts on cities are still subject to discussion in the academic community. There is a clear need to better understand the potential impacts of LRT projects, particularly in contexts other than major cities. In this study, we focus on the Olsztyn tram project, which has been implemented in a city of 173,000 residents situated in northeastern Poland. The paper combines different perspectives and data sources, including a study of residents' stated preferences concerning travel behavior and modelling of housing price effects using the difference-indifferences approach. Our results suggest that the Olsztyn tram project led to a moderate change in travel behavior by increasing the frequency of public transport use but did not result in a substantial shift away from car commuting. Concerning the property market, a decline in prices was observed during the construction phase, but no statistically significant effects were found after completion.
\end{abstract}

\section{Article history:}

Received: April 2, 2019

Received in revised form: July

24, 2019

Accepted: February 2, 2021

Available online: July 22, 2021

\section{Introduction}

Transport and mobility are widely agreed to be among the major challenges for sustainable urban development (Banister, 2008; UN-Habitat, 2013). Large investments in public transport infrastructure, including projects such as light rail transit (LRT) or bus rapid transit (BRT), are seen as key elements in this context, and a phenomenon called "LRT renaissance" has attracted considerable attention in academia over the last few decades (Alpkokin, Topuz Kiremitci, Black, \& Cetinavci, 2016; Babalik-Sutcliffe, 2002). ${ }^{1}$ However, research on the impacts of LRT typically focuses on cities or metropolitan areas counting 500,000 residents or more (Knowles \& Ferbrache, 2016; Macket \& Suttcliffe, 2003). Although a threshold of 300,000 residents has been posited for the delivery of new LRT systems (Knowles \& Ferbrache, 2016, p. 430), there are examples of LRT projects in smaller cities and towns, including notable cases such as Grenoble (163,000 residents), Angers (151,000 residents) and Dijon (155,000) in France, or Freiburg (230,000 residents) in Germany. LRT has been traditionally associated with large and densely populated urban areas. However, according to Newman, Kenworthy, and Glazebrook,

\footnotetext{
${ }^{1}$ Some authors (e.g., Alpkokin et al., 2016) make a distinction between light rail and tramways on the basis of ridership, or project's assumed focus on transport problems of predominantly local or regional (metropolitan) nature. However, in this paper the terms "light rail" and "tram" are used interchangeably.

Copyright 2021 Jędrzej Gadziński \& Adam Radzimski

http://dx.doi.org/10.5198/jtlu.2021.1557

ISSN: 1938-7849 | Licensed under the Creative Commons Attribution - Noncommercial License 4.0
}

The Journal of Transport and Land Use is the official journal of the World Society for Transport and Land Use (WSTLUR) and is published and sponsored by the University of Minnesota Center for Transportation Studies. 
(2013, p. 285), a "changing appreciation of the value of light rail in small cities has occurred." There are now more than 550 LRT systems around the globe, with almost $20 \%$ of them operating in cities and towns with a population under 200,000 (Light Rail Transit Association, 2019; Newman et al., 2013) Many such systems have been constructed in the last three decades.

Recently, it has been argued that LRT could offer a viable solution for cities and towns in Central and Eastern Europe (CEE), which are facing rapidly growing motorization and a declining role of public transport. The post-socialist transition has led to several changes in land use, population distribution and lifestyles, which have resulted in decreasing modal shares of public transport, as well as increased commuting and a growing dependency on the automobile (Tammaru, 2005). Motorization rates in the CEE increased two- or even threefold over the last two decades, reaching levels comparable to Western Europe (Eurostat, 2018). Also, substantial investment has been made in road infrastructure (Pucher \& Buehler, 2005). There appears to be a strong preference for car ownership among young adults in the CEE, with cars being perceived as a status symbol rather than simply a means of meeting one's travel needs (Pojani, van Acker, \& Pojani, 2018).

Most large cities in Central and Eastern Europe already have functioning LRT systems, and some of them, such as Warsaw or Poznań, have made substantial investments in rail-based infrastructure (Gadziński \& Radzimski, 2016; Trojanek \& Głuszak, 2018). Many mid-sized cities in the CEE used to have LRT infrastructures that were dismantled in the post-war period, leaving buses as the only public transport option (Kołoś \& Taczanowski, 2016). Recently the availability of EU funds has opened up the possibility for substantial investment in sustainable mobility. Yet, to our knowledge, Olsztyn, a city of 173,000 residents situated in north-eastern Poland, is the only CEE city to have introduced a new LRT system in the post-socialist period. Thus, we believe that this case could provide valuable insights for cities seeking sustainable urban transport solutions.

Set against this background, this paper aims to contribute to the empirical evidence on the impacts of light rail on property prices and travel behavior by presenting a case study of a recent tram project. The paper offers an approach combining a study of residents' stated preferences with hedonic price modelling. Studies of LRT projects typically focus on one category of impacts, such as changes in travel behavior (Babalik-Suttcliffe, 2002), or - increasingly over the last few years - property price effects (Higgins \& Kanaroglou, 2016). Yet, in our view, combining different perspectives and data sources allows us to provide a broader picture.

The paper is structured as follows: the first section presents a theoretical overview of the impacts of LRT as discussed in the literature, before moving on to present the context of the project under investigation. Following this, we present first the findings in terms of housing price impacts, and then residents' stated preferences concerning travel behavior, satisfaction with the place of living and willingness to pay. Next, the article discusses the findings against the background of the existing literature, and finally, the research is summarized in the concluding section.

\section{Impacts of LRT: A literature overview}

While several urban LRT systems were dismantled during the second half of the 20th century to make room for the growth in car mobility (Mills, 2001), the following decades have seen a surge in investment in rail-based solutions that has been labelled a "rail renaissance" (Alpkokin et al., 2016). Investment in LRT, as well as in other high-capacity public transport solutions such as bus rapid transit (Rodriguez \& Mojica, 2009), is seen as a key element of sustainable urbanization and environmentally conscious mobility. Consequently, urban LRT systems have received considerable attention from academia over the last few years. 
Research on LRT impacts may be grouped into several categories, among which two major branches focus on (1) property prices and (2) travel behavior. Property price impacts are part of the wider economic impacts of LRT, which may also include unlocking sites for development, the stimulation of inward investment or the extension of labor market catchment areas (Knowles \& Ferbrache, 2016). Research on land value uplift originated in North America about half a century ago (Higgins \& Kanaroglou, 2016). Recently, the research has experienced rapid growth, as well as increasing geographical differentiation. It has been suggested that land value uplift may be used as a proxy for capturing the larger social, economic and environmental benefits of an LRT project (Higgins \& Kanaroglou, 2016). However, some recent studies have found only limited positive effects of public transport investment on land value uplift (Dubé, Legros, \& Devaux, 2018; Gadziński \& Radzimski, 2016). It has also been suggested that neighborhood-level housing markets react to an LRT project differently depending on their socio-economic status (Forouhar \& Hasanhkani, 2018).

Some studies have questioned the importance of the economic impacts of LRT, suggesting that transport is not a growth-inducing factor by itself. In the absence of existing demand and growth-inducing policies, transport projects alone do not result in economic growth (Mackett \& Babalik-Sutcliffe, 2003). Thus, some authors prefer the concept of "opportunities" rather than "impacts" of transport projects (Richer \& Hasiak, 2014). The equity of LRT investments and their potentially detrimental effects on vulnerable population groups, e.g., through increased property prices, has also been questioned. However, research on the various social consequences of LRT projects has been surprisingly scarce (Knowles \& Ferbrache, 2016). It has been suggested that value increments due to accessibility improvements be collected through a taxation scheme and redistributed for the benefit of society. Yet, the actual implementation of value-capture schemes has, so far, remained limited. According to some scholars, an overemphasis on economic effects situates LRT projects in a neoliberal agenda that defines growth as the single most important policy objective (Grengs, 2005; Paget-Seekins, 2015).

The sustainable mobility paradigm (Banister, 2008) sees LRT as an instrument of tackling congestion and improving accessibility as well as environmental quality (Babalik-Suttcliffe, 2002). Studies have shown that subject to adequate planning, LRT could drive an increase in public transport use (Engebretsen, Christiansen \& Strand, 2017). It could also encourage the residential relocation of transit-liking people to areas close to public transport stations, allowing them to realize their previously non-revealed preferences (Cao \& Ermagun, 2017). According to the concept of residential self-selection, people tend to make their housing decisions taking into account their travel preferences and neighborhood characteristics (Cao, Mokhtarian, \& Handy, 2009; Klinger, Kenworthy, \& Lanzendorf, 2013). In effect, the results of public transport improvements could be very different in car-oriented housing developments compared to the situation in transit-oriented neighborhoods (TODs), where the inhabitants are accustomed to using rail transport daily.

Empirical studies have only partly confirmed a positive effect of LRT projects on travel behavior. Knowles and Ferbrache (2016) found the effects of LRT on congestion to be mixed. A growing share of sustainable travel modes such as rail does not necessarily indicate a shift of car users towards public transport, as it may result instead from a shift of bus users (Lee \& Senior, 2013). The effects could be reinforced by an optimal location close to potential users (Engebretsen et al., 2017), thus it is important to understand LRT as part of a wider planning and development concept (Cao \& Schoner, 2014).

\section{$3 \quad$ About the Olsztyn tram project}

As a city with less than 200,000 residents, Olsztyn is an unusual setting for a contemporary tram project. It is a particularly interesting case because the city had an operational tram network from 1907 until 
post-war decommissioning in 1965. The idea of reintroduction emerged after Poland acceded to the European Union in 2004. The EU cohesion policy offered an extraordinary opportunity for Poland, and particularly for its least developed eastern regions. In the 2004 to 2013 period alone, 250 projects were co-financed with EU funds with a total value of 26.6 billion PLN (6.3 billion EUR), with a $59.2 \%$ EU contribution. Funding for more than 400 new projects was earmarked until 2017 within the 2014-2020 financial perspective. In order to meet the EU sustainable transport regulations (Pucher \& Buehler, 2005), a substantial share of investment was focused on improvements in the public transport network (Komornicki 2003; Pucher, 1995).

The integrated program of public transport development of Olsztyn (2004) first proposed a tram or trolley bus connecting the city center with densely populated neighborhoods in the southern part of the city (Figure 1), spurring a lively discussion in the local community. The project was approved in 2006 by the Polish government within the EU-funded program for the Eastern regions (Polska Wschodnia). The tram option was eventually chosen over the trolley bus, with an emphasis placed on routes separated from car traffic to ensure undisturbed traffic flows and minimal travel times. The construction process faced some serious challenges, as the company originally chosen in the tender process withdrew from the construction works. Thus, it was not until the end of 2015 that all planned routes became operational.

The new LRT network consists of three lines connecting the historical city center and the main train station with the university campus and large housing estates such as Jaroty and Kormoran (Figure 2). The network consists of 11 kilometers of tracks and 19 tram stops. Total project cost, including construction works and the purchase of vehicles, amounted to 500 million PLN (approx. 120 million EUR). A survey conducted a few months after the inauguration of the LRT showed that the two most popular lines were used by approx. 8,000 passengers per day, whereas the third line serving the university campus attracted approx. 2,000 passengers per day. An extension of the network was approved in 2020.

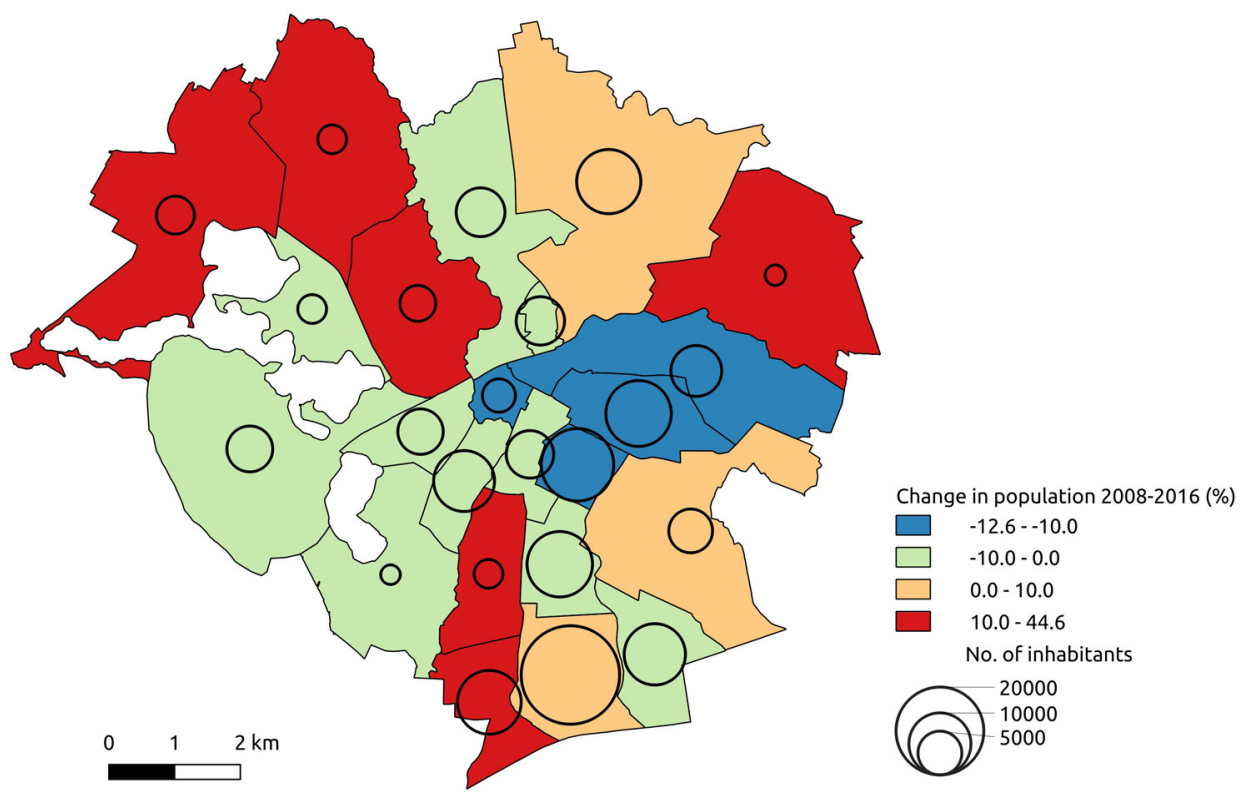

Figure 1. Spatial distribution of population and population change in Olsztyn

An increased number of public transport trips has been observed following the introduction of the trams (Table 1). There was an increase in ticket revenues, but an even higher increase in operating costs as well. Thus, the revenue/operating cost ratio fell below 50\%. Public transport accounts for a $23 \%$ 
modal share in Olsztyn, with the share of car trips amounting to $61 \%$, as well as a $9 \%$ share of cycling (Plan mobilności Miejskiego Obszaru Funkcjonalnego Olsztyna, 2017).

Table 1. Passengers, revenues and operating costs of public transport in Olsztyn

\begin{tabular}{|l|l|l|l|l|l|}
\hline Year & Paid trips (1,000) & All trips* (1,000) & $\begin{array}{l}\text { Revenue (PLN } \\
\text { million) }\end{array}$ & $\begin{array}{l}\text { Operating cost (PLN } \\
\text { million) }\end{array}$ & $\begin{array}{l}\text { Revenue/operat- } \\
\text { ing cost ratio }\end{array}$ \\
\hline 2012 & 31,095 & 37,314 & 34.4 & 54.7 & $62.9 \%$ \\
\hline 2013 & 30,124 & 36,149 & 32.9 & 60.7 & $54.2 \%$ \\
\hline 2014 & 29,062 & 34,875 & 32.4 & 66.2 & $48.9 \%$ \\
\hline 2015 & 29,637 & 35,565 & 31.6 & 71.3 & $44.4 \%$ \\
\hline 2016 & 32,710 & 39,252 & 34.3 & 80.8 & $42.5 \%$ \\
\hline
\end{tabular}

*Including persons legally exempted from public transportation fees

\section{$4 \quad$ Materials and methods}

\subsection{Modelling of housing price impacts}

This paper uses an approach called hedonic price modelling to investigate the impacts of the light rail line on housing prices in the surrounding areas. More specifically, an approach called difference-in-differences is used (Athey \& Imbens, 2006; Bertrand, Duflo, \& Mullainathan, 2004). This technique compares the situations before and after treatment, such as the construction of light rail (Dubé, Legros Thériault, $\&$ Des Rosiers, 2014; Yen, Mulley, Shearer, \& Burke, 2018). Following a specification provided by Yen et al. (2018), with slight modifications, a difference-in-differences model can be formulated as:

$\ln \left(p_{i t}\right)=\beta_{0}+\beta_{1} X_{i t}+\beta_{2} N_{i t}+\beta_{3} L R_{i t}+\beta_{4} T_{i m}+\Sigma \theta_{t} L R_{i t} x \operatorname{Period}_{i t}+\varepsilon_{i t}$

In the formula given above, $p_{i t}$ represents the price at which property $i$ was sold at time point $t$; $X_{i t}$ and $N_{i t}$ represent vectors of property attributes (such as size, building age) and neighborhood attributes (such as distance to schools, kindergartens); $L R_{i t}$ is a catchment variable taking the value of 1 if the property was located within the catchment distance of light rail and 0 otherwise; $T_{i m}$ is the time series variable measuring the number of months $(m)$ that elapsed between 1st January 2008 (start of the investigated period) and the transaction date of property $i$; Period ${ }_{i t}$ is a variable that takes the value of 1 if a property was sold within a specified time interval, and 0 otherwise; and $\varepsilon_{i t}$ is the error term for property $i$ in time $t$. The difference-in-differences estimator, which is given by an interaction of $L R_{i t}$ and $\operatorname{Period}_{i t}$, can be used to test the hypothesis whether there was a difference in property price change over time among properties that were located within the catchment area (treatment group) and outside of it (control group).

A number of studies have highlighted the importance of accounting for spatial effects in hedonic price models (Dubé et al., 2014; Trojanek \& Głuszak, 2018). If spatial autocorrelation is not accounted for, it may lead to biased model results. Spatial models such as a spatial lag model or a spatial error model are based on a matrix of spatial weights $(W)$. The spatial lag model corresponds to a situation in which observations of the dependent variable are assumed to be dependent upon neighboring values. The spatial error model, on the other hand, deals with a possible omission of variables. The decision 
between the spatial lag and the spatial error specification is based on the value of the Lagrange multiplier test (Anselin, Bera, Florax, \& Yoon, 1996). Spatial models used in this paper were estimated using the GeoDaSpace software.

We used a database of apartment sales transactions covering the period from 2008 to 2016 provided by Olsztyn City Hall and geocoded using the Google Maps API. Standard procedures of data cleansing were applied to remove incomplete records as well as non-free market sales. After cleansing, a database counting 11,402 records was obtained (Figure 2).

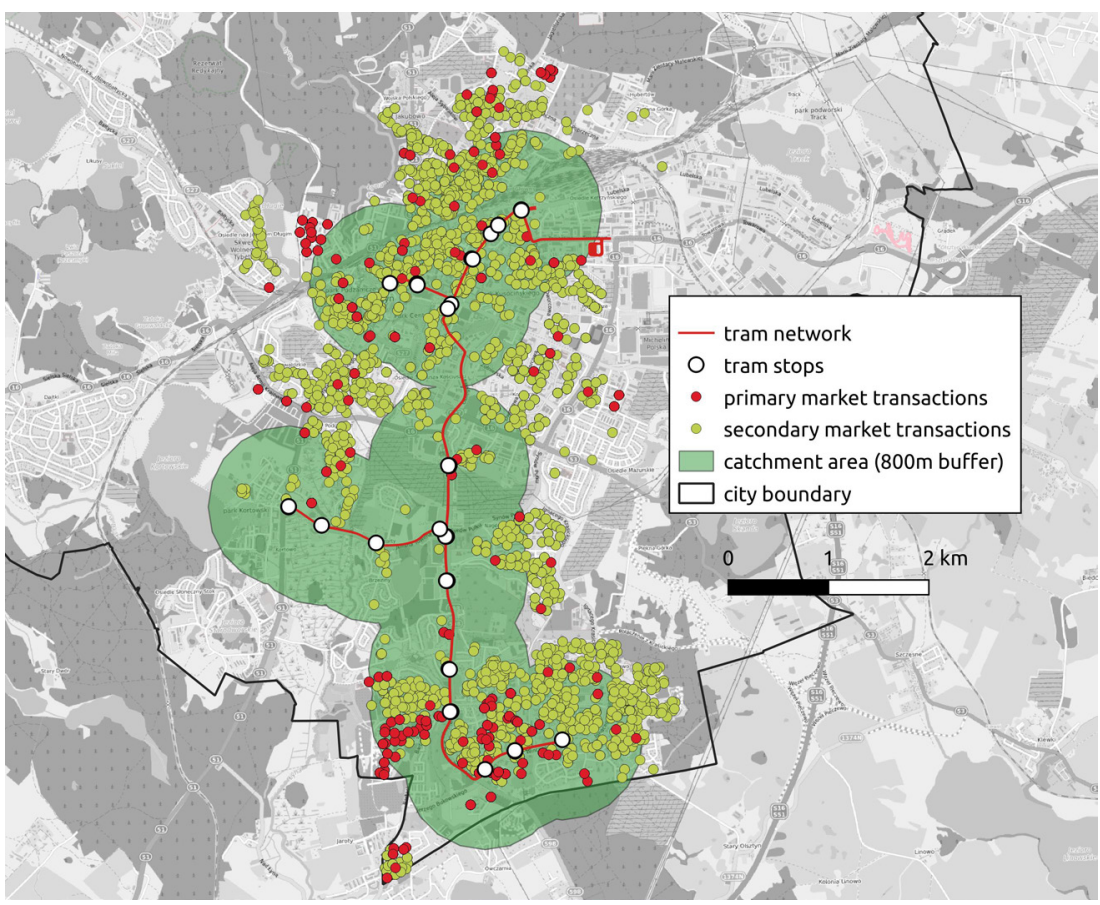

Figure 2. Apartment sale transactions included in the analysis

The original database contained the basic characteristics of a dwelling, such as size, age of the building, and the number of floors. Also, supplemental information was drawn from other available sources. Addresses of schools and kindergartens were drawn from the municipal website, while the locations of recreational areas were imported from OpenStreetMap. Distances to schools, kindergartens, green areas, the university campus and the railway station were calculated in QGIS.

Properties located within 800 meters of tram stations were considered to be in the catchment area (treatment group), while other properties were regarded as control. The academic literature suggests that there is no clear threshold distance for accessibility to transport stations (Guerra, Cervero, \& Tischler, 2013), but for operational reasons distances ranging from 400 meters to 800 meters are typically chosen.

The period variables in the models were measured in two ways. In the first approach, a dummy variable was used for each year. In the other approach, four phases of the Olsztyn tram project were distinguished: phase 0 (pre-announcement) starting on 1st January 2008 and ending with the publication of the final feasibility study in May 2009; phase 1 (announcement) until the publication of tender results in March 2011; Phase 2 (construction) until 31st December 2015, and phase 3 (delivery) until 31st December 2016. While the first approach allows measuring the temporal effects with greater precision, the other reflects more clearly the significant turning points of the project. A full list of explanatory variables is given in Table 2 . 
Table 2. Explanatory variables used in hedonic price modelling

\begin{tabular}{|c|c|c|}
\hline Variable group & Variable & Description \\
\hline \multirow[t]{5}{*}{ Dwelling characteristics } & Dwelling size & Dwelling area in square meters \\
\hline & Building age & Age of the building (years) \\
\hline & Primary market & $\begin{array}{l}1 \text { if property was sold by a housing developer (=primary } \\
\text { market) }\end{array}$ \\
\hline & Monument & 1 if property has monument status \\
\hline & Floors & No. of floors in the building \\
\hline \multirow[t]{5}{*}{ Locational characteristics } & Railway station & $\begin{array}{l}\text { Distance }(\mathrm{km}) \text { from the Olsztyn railway station, used as a } \\
\text { proxy for the CBD }\end{array}$ \\
\hline & Campus & Distance $(\mathrm{km})$ from the university campus \\
\hline & Schools & Distance $(\mathrm{km})$ from the nearest public elementary school \\
\hline & Kindergartens & Distance $(\mathrm{km})$ from the nearest public kindergarten \\
\hline & Green & Distance $(\mathrm{km})$ from the nearest green area \\
\hline \multirow[t]{11}{*}{ Interaction terms } & Phase1_Catchment & 1 if property was sold in Phase 1 within an $800 \mathrm{~m}$ buffer \\
\hline & Phase2_Catchment & 1 if property was sold in Phase 2 within an $800 \mathrm{~m}$ buffer \\
\hline & Phase3_Catchment & 1 if property was sold in Phase 3 within an $800 \mathrm{~m}$ buffer \\
\hline & 2009_Catchment & 1 if property was sold in 2009 within an $800 \mathrm{~m}$ buffer \\
\hline & 2010_Catchment & 1 if property was sold in 2010 within an $800 \mathrm{~m}$ buffer \\
\hline & 2011_Catchment & 1 if property was sold in 2011 within an $800 \mathrm{~m}$ buffer \\
\hline & 2012_Catchment & 1 if property was sold in 2012 within an $800 \mathrm{~m}$ buffer \\
\hline & 2013_Catchment & 1 if property was sold in 2013 within an $800 \mathrm{~m}$ buffer \\
\hline & 2014_Catchment & 1 if property was sold in 2014 within an $800 \mathrm{~m}$ buffer \\
\hline & 2015_Catchment & 1 if property was sold in 2015 within an $800 \mathrm{~m}$ buffer \\
\hline & 2016_Catchment & 1 if property was sold in 2016 within an $800 \mathrm{~m}$ buffer \\
\hline Catchment variable & Catchment area & 1 if property was located in the 800 meters catchment area \\
\hline Time control & Months & $\begin{array}{l}\text { No. of months between the start date }(01.01 .2008) \text { and } \\
\text { transaction date }\end{array}$ \\
\hline
\end{tabular}

\subsection{Stated preferences analysis with household survey data}

A survey of stated preferences was conducted in two neighborhoods located along the new tram line, Kormoran and Jaroty (Figure 3). The aim of the survey was to explore any changes in travel behavior, satisfaction with the place of living and willingness to pay after the opening of the LRT. The interviews were conducted in October 2017 by a group of three trained and instructed interviewers, using structured questionnaires in a face-to-face technique. Randomly selected respondents were visited in their households over a period of five days. The interviews were conducted during working and non-working hours as well as on weekdays and weekends. Gender and age structure were taken into consideration during the selection of respondents. Unfortunately, it was not possible to obtain the demographic characteristics for particular districts. Such selection of the sample structure is a compromise solution and we should remember that the actual demographic structure in selected neighborhoods could differ to some extent from the situation in the whole city. 

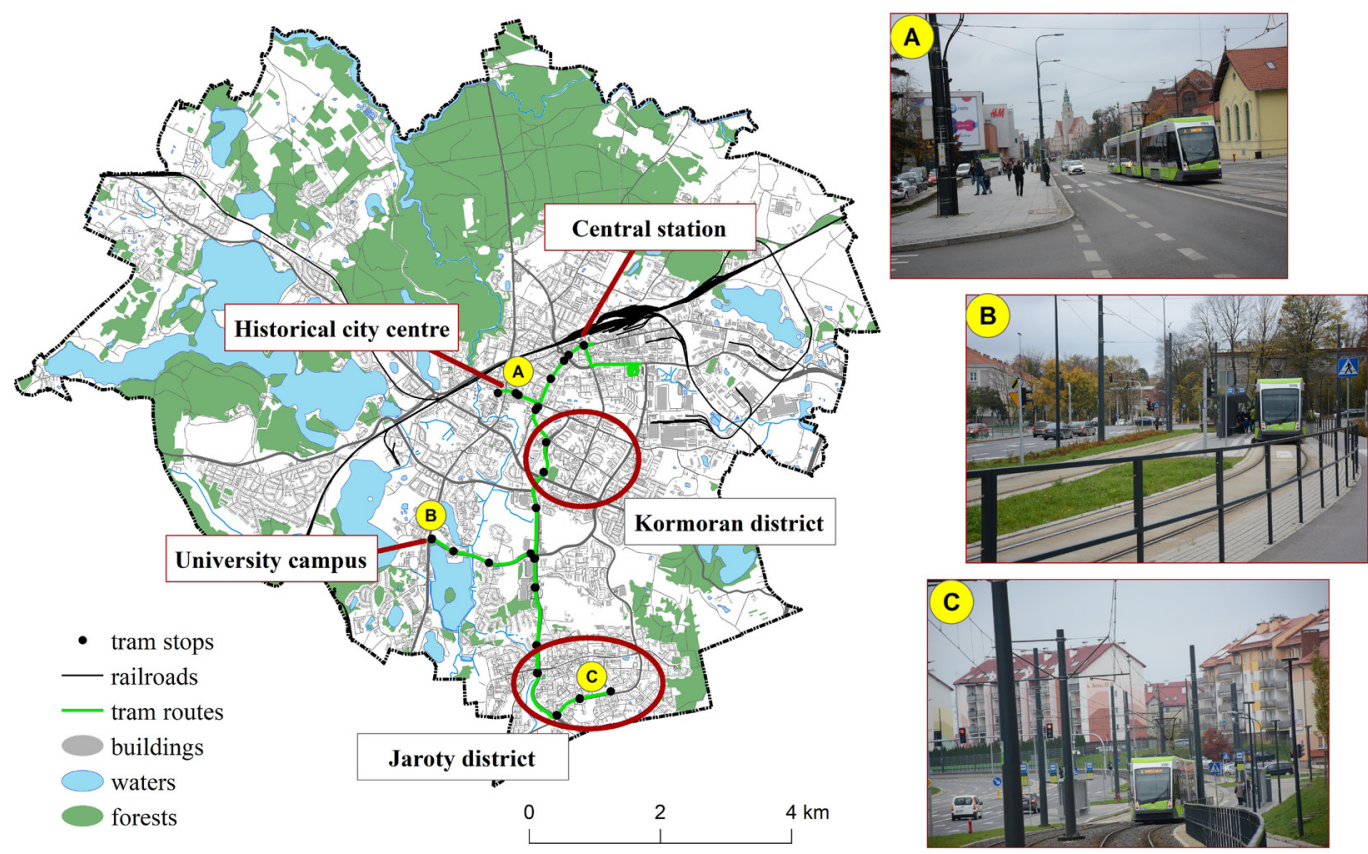

Figure 3. Neighborhoods of Olsztyn chosen for the analysis Photos by Joanna Gadzińska

A total of 510 valid questionnaires were received, including two sub-samples in Jaroty ( 253 respondents) and Kormoran (257 respondents). The interviewed households represented 1,522 inhabitants of these neighborhoods. The main characteristics of the respondents are given in Table 3. 
Table 3. Structure of respondents

\begin{tabular}{|c|c|c|}
\hline & Jaroty & Kormoran \\
\hline Number of respondents & 253 & 257 \\
\hline \multicolumn{3}{|l|}{ Gender } \\
\hline Male & $111(44 \%)$ & $132(52 \%)$ \\
\hline Female & $141(56 \%)$ & $124(48 \%)$ \\
\hline \multicolumn{3}{|l|}{ Age } \\
\hline$<25$ & $25(10 \%)$ & $30(12 \%)$ \\
\hline $25-40$ & $78(31 \%)$ & $100(39 \%)$ \\
\hline $41-60$ & $93(37 \%)$ & $93(36 \%)$ \\
\hline$>60$ & $56(22 \%)$ & $33(13 \%)$ \\
\hline \multicolumn{3}{|l|}{ Education } \\
\hline Primary & $8(3 \%)$ & $5(2 \%)$ \\
\hline Vocational & $47(19 \%)$ & $15(6 \%)$ \\
\hline Secondary & $96(38 \%)$ & $82(33 \%)$ \\
\hline Higher & $101(40 \%)$ & $149(59 \%)$ \\
\hline \multicolumn{3}{|l|}{ Occupation } \\
\hline Studying & $25(10 \%)$ & $35(14 \%)$ \\
\hline Working & $179(71 \%)$ & $187(74 \%)$ \\
\hline Unemployed & $0(0 \%)$ & $0(0 \%)$ \\
\hline Retired & $36(14 \%)$ & $23(9 \%)$ \\
\hline Housekeeping & $12(5 \%)$ & $8(3 \%)$ \\
\hline \multicolumn{3}{|c|}{ Household characteristics } \\
\hline \multicolumn{3}{|l|}{ Size } \\
\hline Total number of residents & 746 & 776 \\
\hline Residents per household & 2.96 & 3.03 \\
\hline Children per household & 0.80 & 0.69 \\
\hline \multicolumn{3}{|l|}{ Legal status } \\
\hline Ownership* & $201(79 \%)$ & $190(75 \%)$ \\
\hline Rented & $52(21 \%)$ & $65(25 \%)$ \\
\hline \multicolumn{3}{|l|}{ Material status** } \\
\hline High-income & $123(49 \%)$ & $110(48 \%)$ \\
\hline Average & $116(46 \%)$ & $119(52 \%)$ \\
\hline Low-income & $12(5 \%)$ & $1(0 \%)$ \\
\hline \multicolumn{3}{|l|}{ Number of cars } \\
\hline Total & 314 & 276 \\
\hline Per household & 1.25 & 1.08 \\
\hline Per person & 0.42 & 0.36 \\
\hline \multicolumn{3}{|l|}{ Number of seasonal tickets } \\
\hline Total & 344 & 311 \\
\hline Per household & 1.37 & 1.21 \\
\hline Per person & 0.46 & 0.40 \\
\hline
\end{tabular}

* Including private and cooperative ownership.

** Declared by household heads (subjective opinion). 


\section{$5 \quad$ Hedonic price modelling results}

Two approaches were used to estimate the impacts of the Olsztyn tram project on property prices. In the first approach, year dummies were used to account for different periods of the project, while in the other approach we divided the project into four phases (prior to announcement, announcement, construction and delivery).

\subsection{Model with year dummies}

In the first stage, a standard ordinary least squares method was used with a Lagrange multiplier test for spatial autocorrelation. We used a distance-based weights matrix and compared Moran's I values for distances of 200 meters, 100 meters and 50 meters. The highest Moran's I value was obtained in the last case, thus the 50 meters matrix was used in all subsequent estimations. Lagrange multiplier results showed that the test statistics for both the spatial lag and the spatial error model were significant, but the p-value for the spatial error model was lower. Thus, we decided to estimate a spatial error model as well as a joint spatial lag and error model (SARMA). A multicollinearity test was also conducted using the variance inflation factor (VIF). For all the explanatory variables, the VIF values were below the threshold value of 10 . Thus, we concluded that multicollinearity was not an issue.

Both the spatial error model and the SARMA approach led to very similar results (Table 4). We found no positive effect of the proximity of light rail on property prices. For most years, the relationships were insignificant, with the exception of 2009, 2012 and 2013, when negative effects on property prices were found. Building age was negatively correlated with sales prices, reflecting the depreciation of housing values over time. However, if a building had a recognized monument status, it would increase the sales price of dwellings. Prices also tended to decrease if the dwelling was located on upper floors, suggesting a preference for lower and more easily accessible floors. Also, housing prices declined with increasing distances to the railway station and the university. As for other locational characteristics, the results were more ambiguous. Distances to schools, kindergartens and green areas were either insignificant or had an unexpected positive sign. There was, however, a clear negative effect of time, reflecting an overall declining trend in housing prices between 2008 and 2016. 
Table 4. Hedonic regression results - models with year dummies

\begin{tabular}{|c|c|c|c|}
\hline & Spatial error & Spatial lag and error (SARMA) & VIF \\
\hline Constant & $11.9327(0.0307)^{* * *}$ & $11.1200(0.3391)^{* * *}$ & - \\
\hline Dwelling size & $0.0116(0.0001)^{* * *}$ & $0.0116(0.0001)^{* * *}$ & 1.15 \\
\hline Building age & $-0.0029(0.0002)^{* * *}$ & $-0.0027(0.0002)^{* * *}$ & 2.70 \\
\hline Primary market & $-0.0543(0.0072)^{* * *}$ & $-0.0549(0.0072)^{* * *}$ & 1.78 \\
\hline Monument status & $0.0612(0.0245)^{*}$ & $0.0538(0.0247)^{*}$ & 1.41 \\
\hline Floors & $-0.0087(0.0015)^{* * *}$ & $-0.0079(0.0015)^{* * *}$ & 1.23 \\
\hline Railway station & $-0.0064(0.0034)$ & $-0.0071(0.0033)^{*}$ & 2.98 \\
\hline University & $-0.0247(0.0044)^{* * *}$ & $-0.0202(0.0047)^{* * *}$ & 1.21 \\
\hline School & $0.0013(0.0144)$ & $0.0055(0.0140)$ & 2.85 \\
\hline Kindergarten & $0.0309(0.0157)^{*}$ & 0.0271 (0.0153). & 2.18 \\
\hline Green & $-0.0114(0.0343)$ & $-0.0159(0.0332)$ & 1.51 \\
\hline Catchment zone & $0.0015(0.0157)$ & $0.0057(0.0156)$ & 9.30 \\
\hline 2009_Catchment & $-0.0260(0.0134)$. & $-0.0258(0.0135)$. & 1.87 \\
\hline 2010_Catchment & $-0.0110(0.0134)$ & $-0.0107(0.0136)$ & 2.36 \\
\hline 2011_Catchment & $0.0192(0.0128)$ & $0.0187(0.0129)$ & 2.92 \\
\hline 2012_Catchment & $-0.0320(0.0135)^{*}$ & $-0.0327(0.0137)^{*}$ & 3.43 \\
\hline 2013_Catchment & $-0.0425(0.0138)^{* *}$ & $-0.0434(0.0140)^{* *}$ & 3.97 \\
\hline 2014_Catchment & $-0.0171(0.0146)$ & $-0.0183(0.0147)$ & 4.73 \\
\hline 2015_Catchment & $-0.0205(0.0154)$ & $-0.0219(0.0156)$ & 4.92 \\
\hline 2016_Catchment & $0.0163(0.0168)$ & $0.0148(0.0170)$ & 4.73 \\
\hline Time trend & $-0.0012(0.0001)^{* * *}$ & $-0.0012(0.0001)^{* * *}$ & 2.76 \\
\hline lambda & $0.6029(0.0119)^{* * *}$ & $0.5877(0.0178)^{* * *}$ & - \\
\hline W_logprice & - & $0.0647(0.0268)^{*}$ & \\
\hline $\mathrm{N}$ & 11,402 & 11,402 & - \\
\hline R-squared & 0.69 & 0.69 & \\
\hline
\end{tabular}

The dependent variable is the natural logarithm of the sale price. Standard errors are given in parentheses. Signif. Codes: ${ }^{* * *} \mathrm{p}<0.001,{ }^{* *} \mathrm{p}<0.01,{ }^{*} \mathrm{p}<0.05, . \mathrm{p}<0.1$

\subsection{Model with project phases}

A similar procedure was applied in the approach using project phases. Again, the Lagrange multiplier test suggested highly significant values for both the spatial lag and spatial error model, with the latter having a lower p-value. Thus, both the spatial error and SARMA models were estimated, as in the previous case.

The results do not differ significantly from models using year dummies. No significant effect on property prices was found in Phase 1 (announcement), whereas in Phase 2 (construction) the coefficient value was negative, suggesting a decline in housing prices. In Phase 3 (delivery) the impact term was again insignificant. Results for other explanatory variables had in most cases the same sign and similar coefficient values as in the models with year dummies. As in the previous case, the lambda term and the weighted dependent variable were highly significant, suggesting the presence of strong spatial autocorrelation (Table 5). 
Table 5. Hedonic regression results - models with project phases

\begin{tabular}{|l|l|l|l|}
\hline & Spatial error & Spatial lag and error (SARMA) & VIF \\
\hline Constant & $11.9347(0.0304)^{* * *}$ & $11.1084(0.3371)^{* * *}$ & - \\
\hline Dwelling size & $0.0116(0.0001)^{* * *}$ & $0.0116(0.0001)^{* * *}$ & 1.15 \\
\hline Building age & $-0.0029(0.0002)^{* * *}$ & $-0.0027(0.0002)^{* * *}$ & 2.70 \\
\hline Primary market & $-0.0530(0.0072)^{* * *}$ & $-0.0537(0.0072)^{* * *}$ & 1.78 \\
\hline Monument status & $0.0599(0.0245)^{*}$ & $0.0523(0.0247)^{*}$ & 1.41 \\
\hline Floors & $-0.0088(0.0015)^{* * *}$ & $-0.0080(0.0015)^{* * *}$ & 1.23 \\
\hline Railway station & $-0.0065(0.0034)$. & $-0.0072(0.0033)^{*}$ & 2.96 \\
\hline University & $-0.0259(0.0043)^{* * *}$ & $-0.0213(0.0046)^{* * *}$ & 1.20 \\
\hline School & $-0.0004(0.0143)$ & $0.0038(0.0140)$ & 2.85 \\
\hline Kindergarten & $0.0324(0.0156)^{*}$ & $0.0286(0.0151)$. & 2.17 \\
\hline Green & $0.0167(0.0342)$ & $-0.0211(0.0331)$ & 1.50 \\
\hline Catchment zone & $-0.0020(0.0140)$ & $0.0019(0.0139)$ & 7.00 \\
\hline Phase1_Catchment & $0.0051(0.0104)$ & $0.0053(0.0105)$ & 2.79 \\
\hline Phase2_Catchment & $-0.0216(0.0109)^{*}$ & $-0.0224(0.0111)^{*}$ & 7.46 \\
\hline Phase3_Catchment & $0.0168(0.0144)$ & $0.0157(0.0145)$ & 3.71 \\
\hline Time trend & $-0.0011(0.0001)^{* * *}$ & $-0.0011(0.0001)^{* * *}$ & 2.11 \\
\hline Lambda & $0.6003(0.0119)^{* * *}$ & $0.5847(0.0178)^{* * *}$ & - \\
\hline W_logprice & - & $0.0658(0.0266)^{*}$ & - \\
\hline N & 11,402 & 11,402 & - \\
\hline R squared & 0.69 & 0.70 & - \\
\hline & & & \\
\hline
\end{tabular}

The dependent variable is the natural logarithm of the sale price. Standard errors are given in parentheses. Signif. Codes: ${ }^{* * *} \mathrm{p}<0.001,{ }^{* *} \mathrm{p}<0.01,{ }^{*} \mathrm{p}<0.05, \mathrm{p}<0.1$

\section{Effects on travel behavior}

The survey results suggest that the Olsztyn tram project resulted in some changes in travel behavior. Some important differences between respondents from both neighborhood sub-samples could also be observed (Table 6). Respondents from Jaroty tend to be more mobile, as they use cars, buses and trams more often than respondents from Kormoran. Surprisingly, the average time needed to reach a tram stop is almost the same in both cases, whereas in the case of bus stops it is higher for Jaroty. 
Table 6. Travel behaviors of respondents from Jaroty and Kormoran

\begin{tabular}{|l|l|l|}
\hline Characteristics & Jaroty & Kormoran \\
\hline \% of respondents using cars everyday & 50.4 & 44.1 \\
\hline \% of respondents using cars at least several times during the week & 68.7 & 60.2 \\
\hline \% of respondents using cars occasionally & 27.4 & 32.8 \\
\hline \% of respondents using buses every day & 17.0 & 9.8 \\
\hline \% of respondents using buses at least several times a week & 51.0 & 30.5 \\
\hline \% of respondents using buses occasionally & 19.8 & 40.6 \\
\hline \% of respondents using trams every day & 15.8 & 14.5 \\
\hline \% of respondents using trams at least several times a week & 43.1 & 37.5 \\
\hline \% of respondents using trams occasionally & 24.5 & 26.2 \\
\hline Average travel time budget per day (in minutes) & 81.1 & 65.7 \\
\hline Average time needed to reach the main activity (work, school - in minutes) & 18.2 & 15.9 \\
\hline Average time needed to reach tram stop (in minutes) & 10.5 & 10.2 \\
\hline Average time needed to reach bus stop (in minutes) & 8.8 & 5.8 \\
\hline Average time needed to reach park place (in minutes) & 1.6 & 2.7 \\
\hline
\end{tabular}

Changes in travel behavior differed for groups of respondents (Table 7). The strongest increase in public transport use was observed for respondents living up to a 10-minute walking distance from new tram stops. These groups travel across the city and visit the city center more often. Reductions in time spent in congestion as well as in time needed to reach the main activities were also noticed.

The effects for car users and persons living at greater distances from the tram seem to be significantly lower, though. Still, many respondents from these groups declared an indirect effect on travel behavior, such as a reduction in traffic congestion or shorter travel times. Some of them started using public transport more often, but a decrease in car usage was only declared sporadically. Generally, the inhabitants of both Kormoran and Jaroty were enthusiasts of the new tram line and saw its impact on individual travel behavior. However, it has not caused a majority of car users to give up driving and switch to public transport. 
Table 7. Changes in travel behavior after LRT opening and its potential impact on surrounding areas

\begin{tabular}{|c|c|c|c|c|c|c|}
\hline \multirow[t]{2}{*}{ Category } & \multicolumn{3}{|c|}{ Jaroty } & \multicolumn{3}{|c|}{ Kormoran } \\
\hline & + & $\mathbf{0}$ & - & + & $\mathbf{0}$ & - \\
\hline \multicolumn{7}{|l|}{ Changes in travel characteristics (\%) } \\
\hline Frequency of travelling & 72.3 & 27.3 & 0.4 & 66.8 & 32.8 & 0.4 \\
\hline Frequency of PT use & 72.7 & 26.9 & 0.4 & 68.8 & 30.9 & 0.4 \\
\hline Frequency of car use & 3.2 & 77.9 & 19.0 & 1.6 & 69.1 & 29.3 \\
\hline Frequency of visiting the city center & 68.7 & 31.0 & 0.4 & 60.5 & 39.5 & 0.0 \\
\hline Time needed to reach the workplace/school & 0.4 & 35.6 & 64.0 & 0.4 & 34.9 & 64.7 \\
\hline Time needed to reach services & 1.6 & 27.3 & 71.1 & 0.4 & 34.4 & 65.2 \\
\hline Time wasted due to congestion & 0.0 & 32.0 & 68.0 & 1.2 & 33.6 & 65.2 \\
\hline \multicolumn{7}{|l|}{ Observed impact of LRT on surrounding areas } \\
\hline Property values around the tramline & 22.5 & 62.8 & 14.6 & 55.5 & 41.4 & 3.1 \\
\hline Workplaces around tramline & 17.0 & 68.0 & 15.0 & 44.5 & 48.0 & 7.4 \\
\hline Housing investments around tramline & 20.6 & 65.2 & 14.2 & 54.5 & 40.8 & 4.7 \\
\hline Ecological character of the city & 85.8 & 12.3 & 2.0 & 71.1 & 21.1 & 7.8 \\
\hline Modern image of the city & 88.1 & 9.5 & 2.4 & 78.1 & 15.2 & 6.6 \\
\hline
\end{tabular}

“+” = increase, “-” = decrease, $0=$ no change

Respondents were also asked about their views concerning the effects of the tram on surrounding areas (Table 7). Interestingly, interviewees from Kormoran, which is located closer to the city center, generally perceived the impacts to be greater. Most agreed that the project caused an increase in property prices and led to new investment in its surroundings. Interviewees from Jaroty were more skeptical about the perceived influence of the tram, which is surprising given that the literature suggests stronger effects in neighborhoods more distant from the city center (Dueker \& Bianco, 1999; Spears, Boarnet, \& Houston, 2017). Also, around 70\% of respondents declared that the LRT strengthened the image of Olsztyn as a modern city and increased its attractiveness for young people. A positive impact on urban ecology was also recognized.

With regard to the willingness to pay, significant differences were found between both neighborhoods (Table 8). Most interviewees from Jaroty would not be willing to pay more for better accessibility to bus and tram stops (this tendency was clear even among public transport users), nor for more parking places. By contrast, respondents from Kormoran were generally more willing to accept higher prices for apartments in a preferable location. 
Table 8. Satisfaction with the place of residence and willingness to pay for selected neighborhood characteristics

\begin{tabular}{|c|c|c|}
\hline Category & Jaroty & Kormoran \\
\hline \multicolumn{3}{|l|}{ Satisfaction with the place of residence (\%) } \\
\hline$\%$ of respondents who are generally satisfied with their place of residence & 74.1 & 81.4 \\
\hline$\%$ of respondents who are satisfied with the location of tram stops & 79.8 & 61.1 \\
\hline$\%$ of respondents who are satisfied with the location of bus stops & 87.7 & 76.3 \\
\hline$\%$ of respondents who are satisfied with the accessibility of parking places & 45.2 & 62.9 \\
\hline$\%$ of respondents who are satisfied with the accessibility of green areas & 31.2 & 59.5 \\
\hline$\%$ of respondents who are satisfied with the accessibility of schools and kindergartens & 45.1 & 68.8 \\
\hline \multicolumn{3}{|l|}{ Willingness to pay (\%) } \\
\hline$\%$ of respondents who would pay more for an apartment closer to the tram stop & 25.9 & 55.1 \\
\hline$\%$ of respondents who would pay more for an apartment closer to the bus stop & 26.7 & 30.2 \\
\hline $\begin{array}{l}\% \text { of respondents who would pay more for an apartment with better accessibility of parking } \\
\text { places }\end{array}$ & 39.4 & 68.4 \\
\hline$\%$ of respondents who would pay more for an apartment closer to the city center & 20.3 & 44.5 \\
\hline$\%$ of respondents who would pay more for an apartment in a lower building & 28.3 & 46.1 \\
\hline$\%$ of respondents who would pay more for an apartment in a low-density neighborhood & 13.5 & 39.5 \\
\hline$\%$ of respondents who would pay more for an apartment surrounded by green areas & 60.4 & 49.2 \\
\hline $\begin{array}{l}\% \text { of respondents who would pay more for an apartment with better accessibility of schools } \\
\text { and kindergartens }\end{array}$ & 15.9 & 45.7 \\
\hline
\end{tabular}

The most important findings from the survey can be summarized in several points. Firstly, the LRT led to some important changes in the selection of transport modes. The effect was stronger for respondents living nearer to the tram stops, and for bus users, many of whom started to use the LRT. However, a reduction in car use was not that clear, even though car drivers also declared some increase in the frequency of public transport usage. Secondly, it seems that the LRT contributed to greater mobility, as most respondents declared an increase in the frequency of travel, as well as more frequent visits to the city center. The opening of the tram network also reduced the amount of time needed to reach the most important daily destinations such as work, school or services. Thirdly, few inhabitants were able to identify the positive effects of the new LRT line on the surrounding areas. Many of them reported an improvement in traffic conditions, but changes in property values, increased investment and new workplaces were observed sporadically.

\section{$7 \quad$ Discussion and conclusion}

This paper looked at the changes brought about by the introduction of the Olsztyn tram project in terms of housing prices and travel behavior. LRT projects have been typically perceived as an important vehicle for promoting sustainable mobility in urban areas. Consequently, such projects have received considerable attention in academia over the past few years. Most contributions have focused on major cities, although many LRT projects are located in small-sized cities and towns as well. Our research was driven by the question of whether such a project could initiate a change towards making public transport a realistic alternative to individual motorization. We hope that by looking at the effects of a local "revolution" in a transport system, like the one that happened in Olsztyn, we would be able to shed more light on this question. 
Some previous studies have found a significant positive effect of LRT on property values. However, in the case of Olsztyn, the difference-in-difference analysis did not suggest a positive impact on housing prices. On the contrary, our models suggest a negative effect during the construction phase, whereas in the announcement and delivery phases there does not seem to be a statistically significant relationship. This finding is consistent with some previous contributions to the literature (Crocker et al., 2000; HassKlau et al., 2004). Such an outcome could result from perceived disadvantages from the construction works, or it could be a consequence of an overall declining trend in housing prices, which had been observed over this period. Concerning the lack of positive housing price effects after completion, it needs to be stressed that the paper has looked only at short-term impacts, whereas some changes could become visible in a longer perspective (Cervero \& Landis, 1997). Also, as suggested by Hess and Almeida (2007), a lack of property price increases should not necessarily be perceived as a negative outcome, as it creates an opportunity for affordable living within accessible neighborhoods.

Concerning changes in travel behavior, our paper found that the tram extended the scope of available transport options, encouraging increased urban mobility, but the car remains the primary means of travel for most respondents. While some previous studies have shown that the LRT had spurred significant changes in travel behavior (Cao \& Schoner, 2014; Engebretsen et al., 2017; Hong, Boarnet, \& Houston, 2016; Knowles, 1996), others have suggested that the situation could be more nuanced, for example, due to bus users rather than car users switching to trams (Lee \& Senior, 2013). In the case of Olsztyn, we could confirm a modest yet positive impact on travel behavior, which is consistent with results in other cities such as Poznań (Gadziński \& Radzimski, 2016) or Bergen (Engebretsen et al., 2017). Most respondents in Olsztyn seem to have a generally positive attitude towards the LRT, but they still use the car regularly. Psychological and cognitive explanations suggest that in a city without a tram the inhabitants could underestimate or overestimate its role due to a lack of previous experience (Bunschoten, Molin, \& van Nes, 2013). Newman et al. (2013) suggest that the benefits of LRT will be greater in a city with high population density and severe congestion problems. Many Polish cities experience problems with increasing traffic congestion, but in Olsztyn, the scale of these problems could have been insufficient to spur a major shift towards LRT.

Our findings seem to be surprising in the light of the media attention given to the new LRT in Olsztyn, which transformed it into a symbol of changing transport policy in Poland. The initiative has been widely reported both by the local and the national media as a successful example of implementing a sustainable mobility agenda with the support of EU funds. However, the findings are consistent with examples from other countries. Research has found limited capitalization of LRT accessibility into property values in a context with modest economic growth and limited scope of service (Hess \& Almeida, 2007).

Nevertheless, the attention that Olsztyn received due to the project has very likely contributed to the promotion of the city and enabled it to build its positive image. What is more, most respondents have a positive attitude towards trams and see their overall positive impact on the city. Further stages of the tram project are still planned, which would allow it to connect other neighborhoods to the tram network. Potentially, this could change the situation and increase the role of trams in the local transport system.

Concerning the planning and policy implications of this research, an examination of the impacts of the Olsztyn tram project in terms of changes in travel behavior and housing price appreciation suggests that light rail could be a feasible solution contributing to sustainable mobility in mid-sized cities. However, a light rail project should rather be seen as a precondition for change, which is likely to depend upon several demographic, economic and cultural factors. Concerning effects on property values, the lack of a positive effect following the completion of the project could be interpreted in different ways. In contexts where infrastructure projects are financed in major part through a levy on land value uplift, 
such a situation could be perceived as a disadvantage. Yet, stable housing prices also mean lower financial pressures for the residents, who may benefit from improvements but do not need to face increased costs of living.

\section{Acknowledgements}

This paper is dedicated to the memory of Jędrzej Gadziński who recently passed away. Grateful thanks are due to two anonymous reviewers and the editor for their valuable comments on earlier versions of the paper. Research presented in the paper received financial support from the National Science Centre, Poland [grant no. UMO-2015/17/D/HS4/00270]. 


\section{References}

Alpkokin, P., Topuz Kiremitci, S., Black, J. A., \& Cetinavci, S. (2016). LRT and street tram policies and implementation in Turkish cities. Journal of Transport Geography, 54, 476-487. https://doi. org/10.1016/j.jtrangeo.2015.10.004

Anselin, L., Bera, A. K., Florax, R., \& Yoon, M. J. (1996). Simple diagnostic tests for spatial dependence. Regional Science and Urban Economics, 26(1), 77-104. https://doi.org/10.1016/01660462(95)02111-6

Athey, S., \& Imbens, G. W. (2006). Identification and inference in nonlinear difference-in-differences models. Econometrica, 74(2), 431-497. https://doi.org/10.1111/j.1468-0262.2006.00668.x

Babalik-Sutcliffe, E. (2002). Urban rail systems: Analysis of the factors behind success. Transport Reviews, 22(4), 415-447. https://doi.org/10.1080/01441640210124875

Banister, D. (2008). The sustainable mobility paradigm. Transport Policy, 15(2), 73-80. https://doi. org/10.1016/j.tranpol.2007.10.005

Bertrand, M., Duflo, E., \& Mullainathan, S. (2004). How much should we trust differencesin-differences estimates? The Quarterly Journal of Economics, 119(1), 249-275. https://doi. org/10.1162/003355304772839588

Bunschoten, T., Molin, E., van Nes, R. (2013). Tram or bus? Does the tram bonus exist? Paper presented at the European Transport Conference, Frankfurt, Germany.

Cao, J., \& Ermagun, A. (2017). Influences of LRT on travel behavior: A retrospective study on movers in Minneapolis. Urban Studies, 54(11), 2504-2520. https://doi.org/10.1177/0042098016651569

Cao, X., \& Schoner, J. (2014). The influence of light rail transit on transit use: An exploration of station area residents along the Hiawatha line in Minneapolis. Transportation Research Part A: Policy and Practice, 59, 134-143. https://doi.org/10.1016/j.tra.2013.11.001

Cao, X., Mokhtarian, P. L., \& Handy, S. L. (2009). Examining the Impacts of residential self-relection on travel behavior: A focus on empirical findings. Transport Reviews, 29(3), 359-395. https://doi. org/10.1080/01441640802539195

Cervero, R., \& Landis, J. (1997). Twenty years of the Bay Area rapid transit system: Land use and development impacts. Transportation Research Part A: Policy and Practice, 31(4), 309-333. https://doi. org/10.1016/S0965-8564(96)00027-4

Crocker, S., Dabinett, G., Gore, T., Haywood, R., Hennebury, J., Herrington, A., ... \& Townroe, P. (2000). Monitoring the economic and development impact of South Yorkshire supertram. Sheffield, England: Center for Regional Economic and Social Research, Sheffield Hallam University.

Dueker, K. J., \& Bianco, M. J. (1999). Light-rail-transit Impacts in Portland: The first ten years. Transportation Research Record: Journal of the Transportation Research Board, 1685(1), 171-180. https:// doi.org/10.3141/1685-22

Dubé, J., Legros, D., \& Devaux, N. (2018). From bus to tramway: Is there an economic impact of substituting a rapid mass transit system? An empirical investigation accounting for anticipation effect. Transportation Research Part A: Policy and Practice, 110, 73-87. https://doi.org/10.1016/j. tra.2018.02.007

Dubé, J., Legros, D., Thériault, M., \& Des Rosiers, F. (2014). A spatial difference-in-differences estimator to evaluate the effect of change in public mass transit systems on house prices. Transportation Research Part B: Methodological, 64, 24-40. https://doi.org/10.1016/j.trb.2014.02.007

Engebretsen, Ø., Christiansen, P., \& Strand, A. (2017). Bergen light rail - effects on travel behaviour. Journal of Transport Geography, 62, 111-121. https://doi.org/10.1016/j.jtrangeo.2017.05.013

Eurostat. (2018). Passenger cars in the EU. Retrieved from https://ec.europa.eu/eurostat/statistics-ex- 
plained/index.php/Passenger_cars_in_the_EU

Forouhar, A., \& Hasankhani, M. (2018). The effect of Tehran metro rail system on residential property values: A comparative analysis between high-income and low-income neighborhoods. Urban Studies, 55(16), 3503-3524. https://doi.org/10.1177/0042098017753089

Gadziński, J., \& Radzimski, A. (2016). The first rapid tram line in Poland: How has it affected travel behaviors, housing choices and satisfaction, and apartment prices? Journal of Transport Geography, 54, 451-463. https://doi.org/10.1016/j.jtrangeo.2015.11.001

Grengs, J. (2005). The abandoned social goals of public transit in the neoliberal city of the USA. City, 9(1), 51-66. https://doi.org/10.1080/13604810500050161

Guerra, E., Cervero, R., \& Tischler, D. (2012). Half-mile circle: Does it best represent transit station catchments? Transportation Research Record: Journal of the Transportation Research Board, 2276(1), 101-109. https://doi.org/10.3141/2276-12

Hass-Klau, C., Crampton, G. R., \& Benjari, R. (2004). Economic impacts of light rail: The results for 15 urban areas in France, Germany, UK and North America. Brighton, UK: Environmental and Transport Planning.

Hess, D. B., \& Almeida, T. M. (2007). Impact of proximity to light rail rapid transit on stationarea property values in Buffalo, New York. Urban Studies, 44(5-6), 1041-1068. https://doi. org/10.1080/00420980701256005

Higgins, C. D., \& Kanaroglou, P. S. (2016). Forty years of modelling rapid transit's land value uplift in North America: Moving beyond the tip of the iceberg. Transport Reviews, 36(5), 610-634. https:// doi.org/10.1080/01441647.2016.1174748

Hong, A., Boarnet, M. G., \& Houston, D. (2016). New light rail transit and active travel: A longitudinal study. Transportation Research Part A: Policy and Practice, 92, 131-144. https://doi.org/10.1016/j. tra.2016.07.005

Integrated program of public transport development. (2004). Olsztyn, Poland: City Hall.

Klinger, T., Kenworthy, J. R., \& Lanzendorf, M. (2013). Dimensions of urban mobility cultures - a comparison of German cities. Journal of Transport Geography, 31, 18-29. https://doi.org/10.1016/j. jtrangeo.2013.05.002

Knowles, R. D. (1996). Transport impacts of greater Manchester's metrolink light rail system. Journal of Transport Geography, 4(1), 1-14. https:/doi.org/10.1016/0966-6923(95)00034-8

Knowles, R., D. \& Ferbrache, F. (2016). Evaluation of wider economic impacts of light rail investment on cities. Journal of Transport Geography, 54, 430-439. https://doi.org/10.1016/j.jtrangeo.2015.09.002

Kołoś, A., \& Taczanowski, J. (2016). The feasibility of introducing light rail systems in medium-sized towns in Central Europe. Journal of Transport Geography, 54, 400-413. https://doi.org/10.1016/j. jtrangeo.2016.02.006

Komornicki, T. (2003). Factors of development of car ownership in Poland. Transport Reviews, 23(4), 413-431. https://doi.org/10.1080/0144164022000026936

Lee, S. S., \& Senior, M. L. (2013). Do light rail services discourage car ownership and use? Evidence from census data for four English cities. Journal of Transport Geography, 29, 11-23. https://doi. org/10.1016/j.jtrangeo.2012.12.002

Light Rail Transit Association. (2019). World systems list. Retrieved from http://www.lrta.org/world/ worldind.html

Mackett, R., \& Babalik Sutcliffe, E. (2003). New urban rail systems: A policy-based technique to make them more successful. Journal of Transport Geography, 11(2), 151-164. https://doi.org/10.1016/ S0966-6923(03)00003-6

Mills, G. (2001). New tramways in France: The case of Montpellier. Transport Reviews, 21(3), 337-352. 
https://doi.org/10.1080/01441640117122

Newman, P., Kenworthy, J., \& Glazebrook, G. (2013). Peak car use and the rise of global rail: Why this is happening and what it means for large and small cities. Journal of Transportation Technologies, 3(4), 272-287. https://doi.org/10.4236/jtts.2013.34029

Paget-Seekins, L. (2015). Bus rapid transit as a neoliberal contradiction. Journal of Transport Geography, 48, 115-120. https://doi.org/10.1016/j.jtrangeo.2015.08.015

Plan mobilności Miejskiego Obszaru Funkcjonalnego Olsztyna. (2017). Olsztyn: City Hall.

Pojani, E., Van Acker, V., \& Pojani, D. (2018). Cars as a status symbol: Youth attitudes toward sustainable transport in a post-socialist city. Transportation Research Part F: Traffic Psychology and Behavior, 58, 210-227. https://doi.org/10.1016/j.trf.2018.06.003

Pucher, J. (1995). The road to ruin? Impacts of economic shock therapy on urban transport in Poland. Transport Policy, 2(1), 5-13. https://doi.org/10.1016/0967-070X(95)93241-P

Pucher, J., Buehler, R. (2005). Transport policy in post-communist Europe. In K. J. Button, \& D. A. Hensher (Eds.), Handbook of transport strategy, policy and institutions, Vol 6 (pp.725-743). Amsterdam: Elsevier.

Richer, C., \& Hasiak, S. (2014). Territorial opportunities of tram-based systems: A comparative analysis between Nottingham (UK) and Valenciennes (FRA). Town Planning Review, 85(2), 217-236. https://doi.org/10.3828/tpr.2014.14

Rodríguez, D. A., \& Mojica, C. H. (2009). Capitalization of BRT network expansions effects into prices of non-expansion areas. Transportation Research Part A: Policy and Practice, 43(5), 560-571. https://doi.org/10.1016/j.tra.2009.02.003

Spears, S., Boarnet, M. G., \& Houston, D. (2017). Driving reduction after the introduction of light rail transit: Evidence from an experimental-control group evaluation of the Los Angeles Expo Line. Urban Studies, 54(12), 2780-2799. https://doi.org/10.1177/0042098016657261

Tammaru, T. (2005). Suburbanization, employment change, and commuting in the Tallinn metropolitan area. Environment and Planning A: Economy and Space, 37(9), 1669-1687. https://doi. org/10.1068/a37118

Trojanek, R., \& Głuszak, M. (2018). Spatial and time effect of subway on property prices. Journal of Housing and the Built Environment, 33(2), 359-384. https://doi.org/10.1007/s10901-017-9569-y

UN-Habitat (2013). Planning and design for sustainable urban mobility: Policy directions. Global report on human settlements. Nairobi: UN-Habitat.

Yen, B. T. H., Mulley, C., Shearer, H., \& Burke, M. (2018). Announcement, construction or delivery: When does value uplift occur for residential properties? Evidence from the Gold Coast Light Rail system in Australia. Land Use Policy, 73, 412-422. https://doi.org/10.1016/j.landusepol.2018.02.007 